\title{
Employees' Perceptions about Islamic Banking and its Growth Potential in Pakistan
}

\begin{abstract}
Burhan Ali Shah ${ }^{1}$, Ghulam Shabbir Khan Niazi², Abdul Majid ${ }^{3}$
Abstract

This paper investigates the perceptions of employees in Islamic banks and Islamic branches of conventional banks regarding practices and growth of Islamic banking in Pakistan. For this purpose, questionnaires were distributed to employees working in these banks. The results reveal that bankers in Islamic banks perceive that Islamic banking is in accordance with Shari' ah and Islamic principles. They hold positive perceptions regarding the practices, objectives and growth of Islamic banking and believe that banks and government are committed towards the development of Islamic banking in the country. Results also show that bankers are confident that Islamic banking will grow and expand in the country in future. The study suggests that the issue of availability of well-trained and skilled employees must be addressed by government and stakeholders for the sustainable growth of Islamic banking in Pakistan.
\end{abstract}

Keywords: Perceptions, practices, growth, bankers, Islamic banking

\section{Introduction}

Islamic banking has gained tremendous growth in last three decades (Chapra, 2007; Ramzan et al., 2012). In certain markets such as Saudi Arabia, market share of Islamic banking is more than 50 percent (Ernst \& Young, 2014) which is a great achievement on part of Islamic banking. However, top twenty Islamic banks in the world consist of 55 percent of total Islamic banking assets and are concentrated in seven countries including Gulf Cooperation Countries (GCC), Malaysia, and Turkey (Ernst \& Young, 2012). Other Islamic countries including Pakistan, Egypt, Jordan, Sudan, and Iran also have initiated supportive infrastructure for development of Islamic banking.

The beginning of Islamic banking in Pakistan can be traced back to 1958 with the establishment of a cooperative bank in the then West Pakistan (Wilson, 2002). However, the formal Islamic banking operations started in 1981 when all branches of commercial banks opened profit and loss sharing (PLS) counters in Pakistan in compliance with SBP's BCD Circular No. 26, issued on December 24, 1980. The

1 Assistant Professor, Quaid-i-Azam University, Islamabad

2 Professor $\mathcal{E}$ Head of Department, Leadership and Management Studies, National Defense University Islamabad

3 Quaid-i-Azam School of Management Sciences, Quaid-i-Azam University, Islamabad 
progress of Islamic banking in Pakistan continued but faced different difficulties for establishing a full-fledged Islamic bank in the country.

Khan (2008) found that from 1980 to 2006, contributions of institutions including government, judiciary and politicians in the development of Islamic banking in Pakistan gave only meagre solution to restore Islamic financial system in the country despite its real effectiveness due to the existence of a deep rooted "conventional system in the financial sectors of Pakistan". He suggested revolutionary steps to be initiated by the government to support and implement Islamic banking system in Pakistan.

The State Bank of Pakistan issued license for the establishment of the first full-fledged Islamic bank in 2002. Consequently, Meezan Bank Ltd. commenced its operation in 2002 as the first full-fledged Islamic commercial bank in Pakistan. Presently, there are six full-fledged Islamic banks and seventeen conventional banks with Islamic branches working in the country (SBP, Quarterly Compendium: Banking Statistics, December 2015). The list of these banks is attached in appendix-A. Presently there are a total of 2075 Islamic banking branches and sub-branches operational in the country (SPB, 2015).

Table 1 shows that Islamic banking (IB) gained 9\% to 10\% share in banking industry of Pakistan. According to SBP (2013), assets and deposits of Islamic banks reached to Rs. 926 billion and Rs. 775 billion respectively by end of September, 2013. In the same period the share of Islamic banking industry in terms of assets and deposits reached to $9.5 \%$ and $10.1 \%$ of the total banking sector of Pakistan, respectively. Net financing and investment of Islamic banking also reached Rs.711 billion at the end of September, 2013 and gained 9.1\% share of the total banking industry in Pakistan.

Table 1: Industry Progress and Market Share (Rupees in Billions)

\begin{tabular}{|c|c|c|c|c|c|c|c|c|c|}
\hline & \multicolumn{3}{|c|}{ Industry Progress } & \multicolumn{3}{c|}{ Growth (YoY) } & \multicolumn{3}{c|}{ Share in Industry } \\
\cline { 2 - 11 } & Sep-12 & Jun-13 & Sep-13 & Sep-12 & Jun-13 & Sep-13 & Sep-12 & Jun-13 & Sep-12 \\
\hline Total Assets & 742 & 903 & 926 & $30.5 \%$ & $27.0 \%$ & $24.8 \%$ & $8.1 \%$ & $9.0 \%$ & $9.5 \%$ \\
\hline Deposits & 628 & 771 & 775 & $35.6 \%$ & $28.0 \%$ & $23.5 \%$ & $9.3 \%$ & $9.9 \%$ & $10.1 \%$ \\
\hline $\begin{array}{c}\text { Net Financing \& } \\
\text { Investment }\end{array}$ & 571 & 700 & 711 & $37.9 \%$ & $28.9 \%$ & $24.6 \%$ & $7.8 \%$ & $8.8 \%$ & $9.1 \%$ \\
\hline $\begin{array}{c}\text { Total Islamic Bank- } \\
\text { ing Institution }\end{array}$ & 18 & 19 & 19 & - & - & - & - & - & - \\
\hline $\begin{array}{c}\text { Total No. of } \\
\text { Branches }\end{array}$ & 977 & 1115 & 1161 & - & - & - & - & - & - \\
\hline
\end{tabular}

(Source: State Bank of Pakistan. Islamic Banking Bulletin July-Sep 2013) 
For appropriate operations of Islamic banking, properly skilled human resource is an essential requisite. The bankers working in Islamic banks are supposed to have sufficient knowledge for understanding the differences between Islamic and conventional banking. Unless they know these two major banking tenets, real Islamic banking in the country could not be flourished as per requirements of the Shari'ah.

Pakistan witnessed a significant growth rate of $10 \%$ in the country's banking system during the last decade and is expected to be doubled by the year 2020 (SPB, 2013). However, the lack of experienced Islamic bankers remained a serious issue and needed to be addressed for the development of Islamic banking in Pakistan (Malik, Malik, \& Mustafa, 2011; Anwar, 2013; Zamil, 2014). The success of Islamic banking largely depends upon the expertise, skills, knowledge, efficiency and experience of employees' working in those banks. Bankers need to possess sufficient knowledge for understanding the differences between Islamic and conventional banking for promoting real Islamic banking in the country. The understanding of bankers working in Islamic banks should be reflected from their perceptions towards Islamic banking.

The core objective of this study is to evaluate the perceptions of bankers about Islamic banking who are working in Islamic as well as Islamic branches of conventional banks. In order to examine the desired aim, following sub-objectives are developed for the purpose of this study. First objective is to investigate bankers' perceptions regarding the correspondence of Islamic banking with Shari'ah. The second objective is to investigate bankers' perceptions about the difference between products and services of Islamic and conventional banks and to know if they truly address the reservations people have with conventional banking in Pakistan. The third objective is to know whether Islamic bankers have sufficient knowledge, experience, professionalism and skills to contribute in the development of Islamic banking. And the fourth objective is to explore deficiencies in proper marketing of Islamic banking for its expansion and awareness. The study is confined to Islamic banking of Pakistan, i.e. it focuses on perceptions of only those employees who are working in Islamic banks and conventional banks with Islamic banking branches in Pakistan.

Rest of the paper is organized as follows. Section 2 deals with a brief literature review covering practices, performance, and growth of Islamic banking. It also includes extensive review on employees' perceptions towards Islamic banking. Theoretical framework and hypotheses of study are also included at the end of Section 2. Section 3 describes the research methodology along with other associated details including operationalization of variables, the research design, variables, scale of measurement and data analysis techniques. Section 4 presents data analysis and discussion in detail. Section 5 concludes the study's findings and gives recommendations. 


\section{Literature Review}

This section presents the review of literature regarding Islamic banking practices, performance, growth, and employees' perceptions towards Islamic banking. Theoretical framework and hypothesis are also presented at the end of this section.

\subsection{Islamic Banking}

Islamic banking is considered more ethical and moral than conventional banking (Hassan \& Latif, 2009; Khan \& Bhatti, 2008; Mahomedy, 2013; Muhamad, Melewar, \& Alwi, 2012; Shakespear \& Harahap, 2009). Islamic banking cares for all social aspects of human life. Islamic Shari'ah strictly bans charging of interest in any transaction (Al-Quran, 2:278, 279, 3:130, 4:61, 30:39). Islam strongly prohibits any sort of speculation, hording of wealth and charging of interest. This is because such acts create evils and are harmful for the health of society. Islam believes in a just and fair economic system which promotes equality among the members of society (Shah \& Niazi, 2009). Hassan and Latif (2009) also suggested that by following the teachings of Islamic Shari'ah, we can make world a better place for humans to carry economic activities. While commenting on the purpose of business, they suggested that for maximizing shareholders' value in the long run, organizations needed to contribute to social undertakings.

Shakespear and Harahap (2009) identified certain basic requirements for the establishment of an Islamic economic system comprising of "no interest, strong ethics, no inflation, free market and end to all irrelevant activities that speculate market productivity and social justice". They observed a numbers of deficiencies inherent in capitalist economic system leading to unjustifiable distribution of wealth. They found Islamic banking and finance a way to forward a balanced and equal distribution of wealth in the society.

A study on the global financial crisis of 2007-08 by Trabelsi (2011) suggested certain preventive steps which supported the Islamic economic system. Trabelsi criticized that capitalist system was not a welfare economic system in the world due to unequal distribution of wealth. On the other hand, Mahomedy (2013) desired the Islamic economic system to meet the economic needs of the Muslims. Islamic economic system is not complete without a proper Islamic banking system. However, the viability of Islamic banking utilizing only the name of Islam as marketing tool is not sufficient (Vahed \& Vawda, 2008). It needs further serious efforts to accomplish and promote an Islamic economic system for the Muslims. Laldin (2008) pointed out that improvements in management skills, Shari'ah rules, and universal acceptability of Islamic banking in the world were key issues required to be addressed. 
Khan and Bhatti (2008), on the other hand, observed that Islamic finance has successfully drawn worldwide attention of investors in recent years. Islamic banking emerged as a hub of finance in Middle East, South Asia and Indian subcontinent with an unexpected growth. It has the potential to capture major Muslim countries and financial markets. It further will extend ahead to grab other ethical groups in future.

\subsection{Individuals and Employees' Perceptions towards Islamic Banking}

Ahmad and Haron, (2008), and Rustam, Bibi, Zaman, Rustam, and Haq (2011) studied corporate customers' perceptions towards Islamic banking and observed potential for growth of Islamic banking. The cost of products and service quality were also identified important factors for future growth of Islamic banking and for attraction of customers towards Islamic bank (Dusuki \& Abdullah, 2007). In the long-term, Islamic banks should be novel in addressing the demands of customers for the growth of Islamic banking (Echchabi \& Olaniyi, 2012).

Retail customers seem to be more familiar with Qard e Hasana and Musharakah but not with other related products and services offered by Islamic banks, though they have immense attachment and commitment towards Islamic banking products and services. Religion, profitability, community service and unique services were identified as customers' priorities for choosing Islamic banking products and services (Gait \& Worthington, 2015). However, Vahed and Vawda (2008) observed that customers were familiar with products and services of Islamic banks. They further proposed that Islamic banking was also viable in a non-Muslim country.

Ramzan et al. (2012) found that individuals and business customers had confidence in Islamic banking and suggested proper training of employees and development of innovative products and services for improved productivity of Islamic banks.

According to Zainol, Shaari, and Ali (2008), Islamic bankers hold positive perceptions towards Islamic banks' products and services. However, employees were found with limited knowledge regarding objectives of Islamic banking. Most of the employees were found with less experience but sufficient knowledge of products and services before joining Islamic banks. Therefore, the management needed to train their employees in Islamic banking products and services, Shari'ah rules and principles. However, Ali and Farrukh (2013) found Islamic banks' employees confident, well trained, and knowledgeable regarding products and services. Rostamy (2009) suggested that banks' managers should initiate changes to meet customers' expectations. Furthermore, banks should focus on customer oriented action plans to satisfy customers' needs via maintaining service quality, and continuous improvement of products and services. 
The development of Islamic banking, like other banks, significantly depends upon the human resource which is responsible for successful operations of Islamic banks. Their knowledge and skills are important for further development of Islamic Banks. The perceptions of Islamic bankers are important to be investigated for knowing their understanding. As Islamic banking is still in its infancy and its growth mainly depends upon the employees and management of banks, therefore the perceptions of service providers at branch level towards practices and growth of Islamic banks are very important to be explored. Consequently, this study would help to understand the perceptions of Islamic bankers regarding Islamic banking products and services, experience and skills they gain in Islamic banks, marketing of Islamic banks' products and services, and future potential of Islamic banks in the country.

\subsection{Theoretical Framework}

Determining bankers' perceptions towards Islamic banking practices and growth in Pakistan

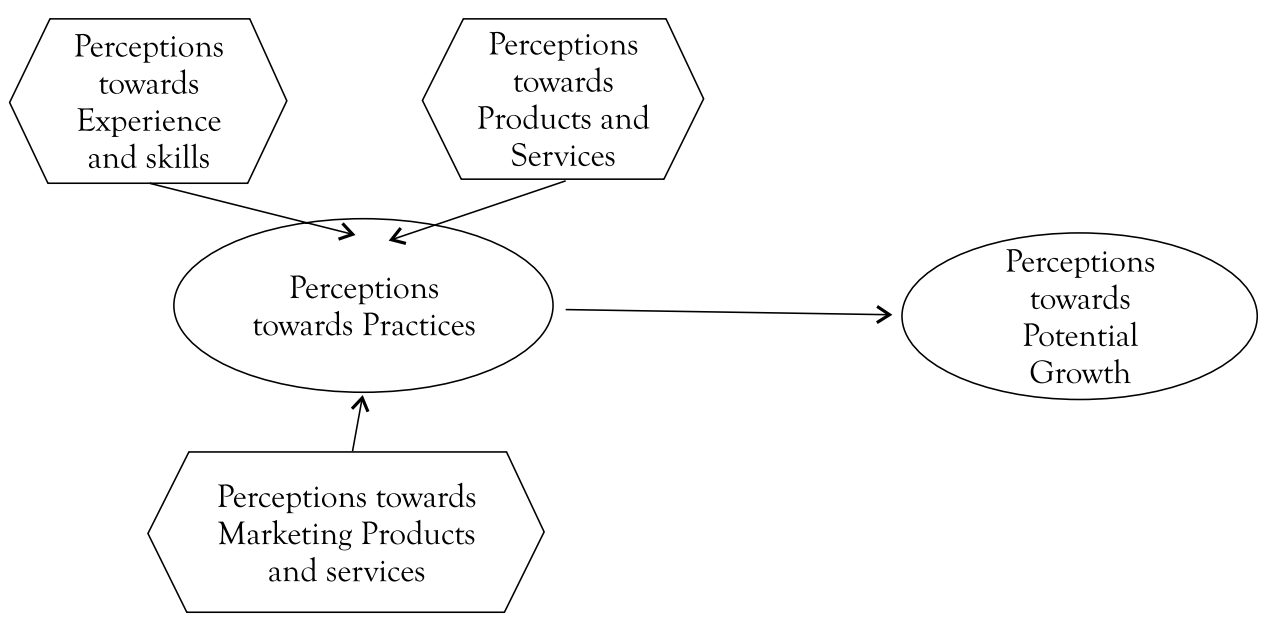

Figure 1: Model of the Study

The proposed model depicts relationship among various variables regarding bankers' perceptions towards IB. The employees' perceptions regarding products and services, experience and skills, marketing of products and services are connected to IB practices. As employees working in Islamic banks have better understanding of Islamic bank practices, therefore it is important to know what they perceive about practices of products and services according to Shari'ah. The overall perceptions of employees regarding practices are linked with perceptions towards potential growth of IB. 


\subsection{Hypothesis Development}

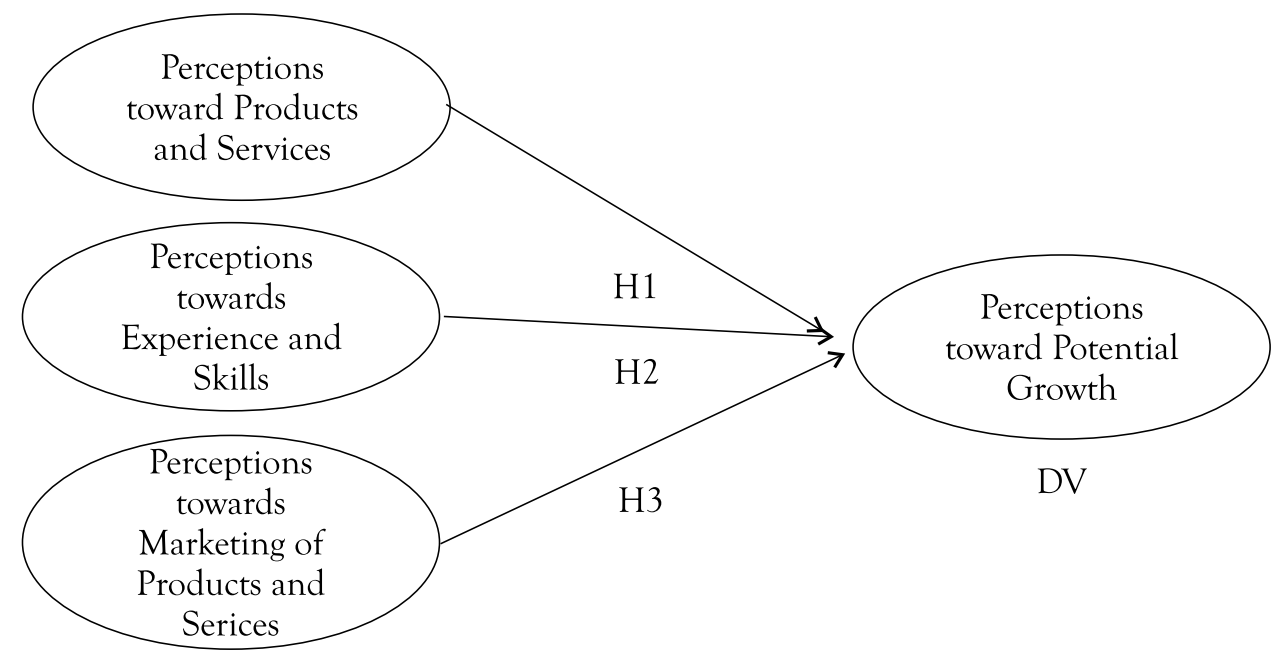

IV

Figure 2: Hypothesis Development of Study

\subsection{Bankers' Perceptions towards Islamic Banking Product and Services}

Bakers' perceptions on products and services of Islamic banks were found significantly positive (Zainol et al., 2008). They found that Islamic banking products and services were differentiated by Shari'ah based on Islamic principles. It could positively and directly affect the growth of Islamic banks in terms of size and customers and efficiencies. On the basis of discussion and evidence, the following hypothesis is developed.

$\mathrm{H}_{1}$ : Bankers' perceptions towards Islamic banking products and services have significant impact on growth of Islamic banking in Pakistan.

\subsection{Bankers' Perceptions towards Experience and Skills Gained in Islamic Banks}

Ali and Farrukh (2013) found employees of Islamic banks well experienced and confident. According to Zainol et al. (2008) Islamic banking employees had sufficient knowledge about the products and services. Anwar (2013) observed that the success of Islamic banking largely depended upon the expertise, skills, knowledge, efficiency and experience of employees' and management. It was observed that employees' knowledge, experience and skills could increase output of an organization and that 
employees' experience and skills have a positive relationship with growth of Islamic banks. Based on these arguments, the following hypothesis is formulated.

$\mathrm{H}_{2}$ : Bankers' perceptions towards experience and skills gained in Islamic banks affect potential growth of Islamic banking in Pakistan.

\subsection{Bankers' Perceptions towards Marketing of Islamic Banking Products and Services}

Creating public awareness and promotion are the key contributors for the development of Islamic banking in Pakistan (Anwar, 2013). The public awareness could be created through different tools which fall under the marketing of products and services of Islamic banks. The commitment of banks and government for promotion of Islamic banking further contribute to the growth of Islamic banking in the country. To understand employees' perceptions towards marketing of products and services of Islamic banks with potential growth, the following hypothesis is developed.

$\mathrm{H}_{3}$ : Bankers' perceptions towards marketing of products and services affect potential growth of Islamic banking in Pakistan.

\section{Research Methodology}

\subsection{Sample Size and Selection Procedure}

Islamic banks and conventional banks with Islamic banking branches constituted the population of this study. There were 1161 of such branches in total in whole Pakistan for this purpose. Geographically, Islamabad, Karachi, Peshawar, Lahore and Quetta had the concentration of 56 percent of all Islamic banking branches in the country.

The study uses purposive (non-probability) sampling technique following Fauziah, Taib, Ramayah, and Abdul Razak (2008), and Marimuthu, Wai Jing, Phei Gie, Pey Mun, and Yew Ping (2010). The reason for this sampling technique was to select bankers in Islamic banks who play a front-line role in providing services to customers. This is because their perceptions were much important for this study rather than randomly selecting all Islamic banks' employees whose perceptions were not relevant to the purpose of the study.

300 employees from 42 Islamic banking branches in Islamabad are selected as sample for the purpose of this study. However, only 239 employees responded affirmatively and returned the questionnaires duly filled. 
This sample size is enough to determine employees' perceptions towards Islamic banking practices and growth in Pakistan based on the precedents set by previous studies (Loo, 2010; Rustam et al. 2011; Abdullah, Sidek, \& Adnan, 2012) where the sample size was limited to maximum of 200 numbers of respondents.

\subsection{Data Collection Methods}

Data is collected through a well-structured and self-administrated questionnaire (attached in the appendix), distributed among the concerned employees of Islamic banks in Islamabad. The total numbers of Islamic banking branches in Islamabad are 61 which make 5.25 percent of the total Islamic banking branches in the country (SBP, 2013).

\subsection{Time Horizon}

The present study collects primary data at a single point in time, i.e. cross-sectional. It collected the data in a duration of three weeks.

\subsection{Measurement of Variables}

\subsubsection{Bankers' Perceptions towards Islamic Banking Products and Services}

First variable consists of eight items of which two items, PLS concept and Riba, are adopted from the study of Zainol et al. (2008) with little modifications. The remaining six items are related to Shari'ah concept, viable alternatives to conventional banking, social and welfare economics addressing reservation of Muslims, innovative products and services, and service quality of products and services of Islamic banks. These items are derived from review of existing literature and reports published by SBP (Islamic Banking Bulletin July-Sep, 2013). Figure 3 shows the perceptions of bankers towards products and services schematically.

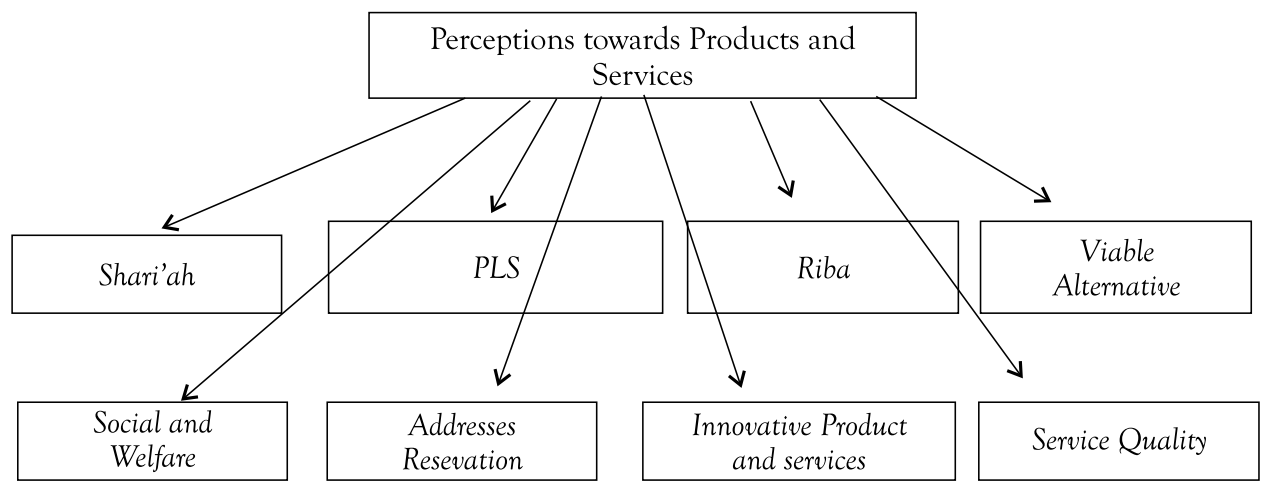

Figure 3: Perceptions towards Products and Services 


\subsubsection{Bankers' Perceptions towards Experience and Skills Gained in Islamic Banks}

Second variable of the study is measured through a set of five items adopted from the study of Zainol et al. (2008). These include: employees' training and exposure on products and services, employees' capability to solve customers' problems, knowledge of employees, training and exposure before assuming the current seat, and encouragement to attain short-courses, seminars and conferences. Figure 4 shows the perceptions of bankers towards experience and skills schematically.

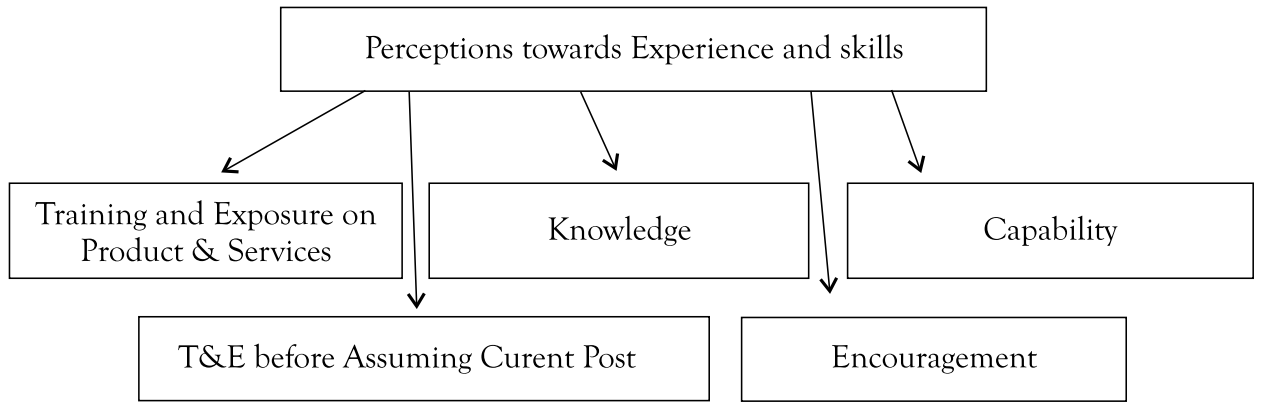

Figure 4: Perceptions towards Experience and Skills

3.4.3. Bankers' Perceptions towards Marketing of Islamic Banking Products and Services

Third variable is measured by a set of five items. Three of the items, i.e. marketing and promotion of Islamic banking products and services, marketing in effective manner of products and services, and government's commitment for the development of Islamic banking, are adopted from the study of Zainol et al. (2008) with little modifications. The remaining two items, marketing tools utilized by Islamic banks, and public awareness creations, are derived from the literature review and SBP published report (Islamic Banking Bulletin July-Sep, 2013). Figure 5 shows the perceptions of bankers towards marketing of Islamic banking products and services schematically.

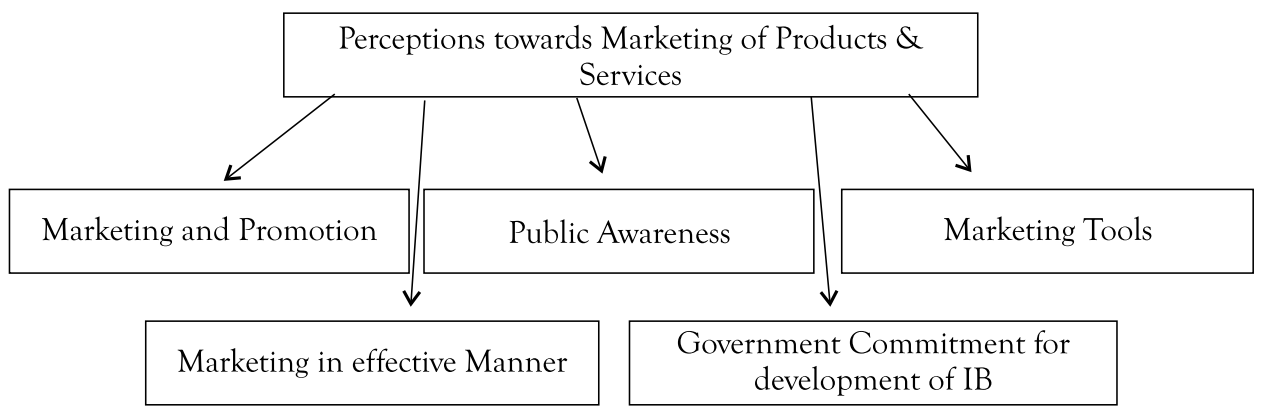

Figure 5: Perceptions towards Marketing Islamic Banking of Products and Services 
3.4.4. Bankers' Perceptions towards Potential Growth of Islamic Banking in Pakistan

The fourth variable of study consists of four items of which three items i.e. use of Islamic banking products and services by individual customers and by corporate customers, and a set target of $20 \%$ market share, are borrowed from the study of Zainol et al. (2008) with little modifications. The remaining one item regarding expansion of Islamic banking in the country is developed particularly for the purpose of the study. Figure 6 shows the perceptions of Islamic bankers towards potential growth schematically.

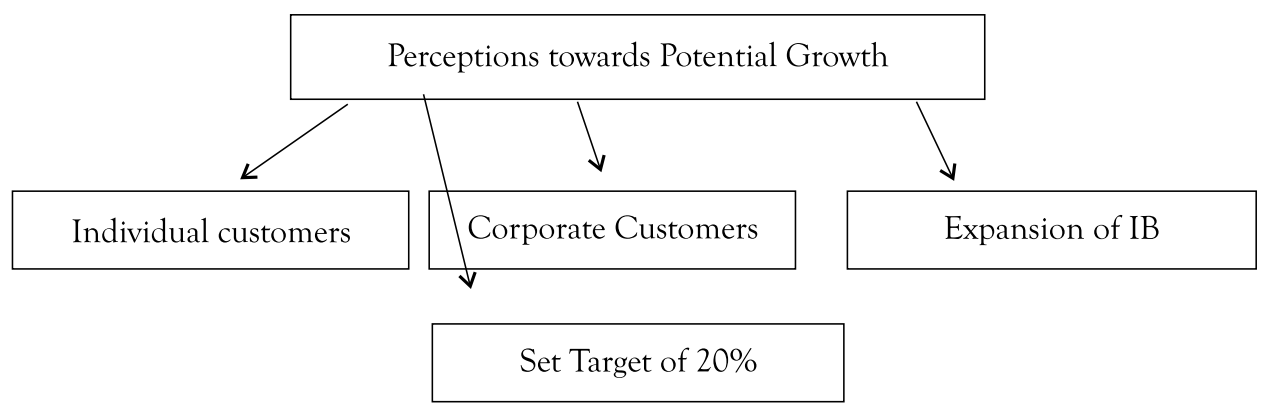

Figure 6: Perceptions of Islamic Bankers towards Potential Growth

\subsection{Scale}

Following Zainol et al. (2008), the current study uses a five-point Likert scale for its items, ranging from Strongly Disagree $=1$ to Strongly Agree $=5$.

\subsection{Measurement of Reliability of the Instrument}

The inter-item reliability of each variable is also confirmed using Cronbach's Alpha. Table 2 presents the score for each variable. As the Alpha score for each variable is greater than the cut-off point, i.e. 0.70 (Santos, 1999), this confirms the inter-item reliability of the instrument.

Table 2: Reliability Statistics

\begin{tabular}{|c|c|c|c|c|c|c|c|}
\hline $\begin{array}{c}\text { Cronbach } \\
\text { Alpha } \\
\text { (BPTPS) }\end{array}$ & $\begin{array}{c}\mathrm{N} \text { of } \\
\text { Items }\end{array}$ & $\begin{array}{c}\text { Cronbach } \\
\text { Alpha } \\
\text { (BPTES) }\end{array}$ & $\begin{array}{c}\mathrm{N} \text { of } \\
\text { Items }\end{array}$ & $\begin{array}{c}\text { Cronbach } \\
\text { Alpha } \\
\text { (BPTES) }\end{array}$ & $\begin{array}{c}\mathrm{N} \text { of } \\
\text { Items }\end{array}$ & $\begin{array}{c}\text { Cronbach } \\
\text { Alpha } \\
\text { (BPTES) }\end{array}$ & $\begin{array}{c}\mathrm{N} \text { of } \\
\text { Items }\end{array}$ \\
\hline .758 & 8 & .788 & 5 & .830 & 5 & .730 & 4 \\
\hline
\end{tabular}

\subsection{Model of the Study}

Equation (1) shows the empirical model of the study. 
$\mathrm{BPTPG}_{i}=\alpha+\beta_{1}$ BPTPS $_{i}+\beta_{2}$ BPTES $_{i}+\beta_{3}$ BPTMPS $_{i}+\varepsilon_{i}$

Where,

BPTPG $_{i}=$ Bankers' perceptions towards potential growth of Islamic banking in Pakistan.

BPTPS $_{i}=$ Bankers' perceptions towards Islamic banking products and services.

BPTES $_{i}=$ Bankers' perceptions towards experience and skills gained in Islamic banks.

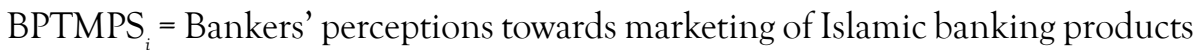
and services

\section{Analysis and Results}

\subsection{Demographic Profile of Respondents}

As mentioned before, a total of 239 out of 300 questionnaires were returned by the respondents. This shows the response rate of $79.66 \%$. Table 3 shows the details of respondents' profiles.

Table 3: Bound Test

\begin{tabular}{|c|c|c|}
\hline Variable / Concept & Categories / Brackets & Proportion in Total \\
\hline Gender & Male & $78.7 \%$ \\
\hline & Female & $21.3 \%$ \\
\hline Age in years & $20-25$ & $18.4 \%$ \\
\hline & $26-30$ & $40.2 \%$ \\
\hline & $31-35$ & $23.8 \%$ \\
\hline & $36-40$ & $11.3 \%$ \\
\hline & $41-45$ & $4.6 \%$ \\
\hline & Above 45 & $1.7 \%$ \\
\hline Education levels & Bachelor's degree & $24 \%$ \\
\hline & Master & $62.8 \%$ \\
\hline & MS/M.Phil, & $9.6 \%$ \\
\hline & PhDs & $0.8 \%$ \\
\hline & Others & $2.1 \%$ \\
\hline & Branch manager & $9.6 \%$ \\
\hline Designation & \multicolumn{2}{|}{} \\
\hline
\end{tabular}




\begin{tabular}{|c|c|c|}
\hline & Operation officers & $29.3 \%$ \\
\hline & Lending officers & $8.5 \%$ \\
\hline & Seniors officers & $26.8 \%$ \\
\hline & Relationship manager & $7.9 \%$ \\
\hline Bank category & Others & $18.0 \%$ \\
\hline & Full-fledged Islamic banks & $59.4 \%$ \\
\hline & $\begin{array}{c}\text { Islamic branches of Conven- } \\
\text { tional banks }\end{array}$ \\
\hline
\end{tabular}

\subsection{Descriptive Statistics of Variables}

\subsubsection{Bankers' Perceptions towards Islamic Banking Products and Services}

Table 4 presents descriptive statistics for eight items of the first variable, i.e. bankers' perceptions towards Islamic banking products and services (BPTPS). From the mean values of items it is observed that employees' perceptions towards Islamic products and services are positive.

Table 4: Descriptive Statistics (BPTPS)

\begin{tabular}{|c|c|c|c|c|c|}
\hline & N & Minimum & Maximum & Mean & Std. Deviation \\
\hline BPTPS_1 & 239 & 2 & 5 & 4.61 & .539 \\
\hline BPTPS_2 & 239 & 2 & 5 & 4.43 & .559 \\
\hline BPTPS_3 & 239 & 2 & 5 & 4.49 & .628 \\
\hline BPTPS_4 & 239 & 2 & 5 & 4.17 & .728 \\
\hline BPTPS_5 & 239 & 1 & 5 & 4.19 & .765 \\
\hline BPTPS_6 & 239 & 1 & 5 & 4.06 & .692 \\
\hline BPTPS_7 & 239 & 2 & 5 & 4.07 & .691 \\
\hline BPTPS_8 & 239 & 1 & 5 & 4.00 & .830 \\
\hline Valid N (list wise) & 239 & & & & \\
\hline
\end{tabular}

4.2.2. Bankers' Perceptions towards Experience and Skills Gained in Islamic Banks

Table 5 presents descriptive statistics for five items of the second variable, i.e. bankers' perceptions towards experience and skills gained in Islamic banks (BPTES). From the mean values of items it is observed that employees perceptions about their experience and skills gained during job are positive. 
Table 5: Descriptive Statistics (BPTES)

\begin{tabular}{|c|c|c|c|c|c|}
\hline & N & Minimum & Maximum & Mean & Std. Deviation \\
\hline BPTES_1 & 239 & 2 & 5 & 4.26 & .696 \\
\hline BPTES_2 & 239 & 2 & 5 & 4.06 & .639 \\
\hline BPTES_3 & 239 & 2 & 5 & 4.32 & .629 \\
\hline BPTES_4 & 239 & 2 & 5 & 4.15 & .704 \\
\hline BPTES_5 & 239 & 1 & 5 & 4.32 & .715 \\
\hline Valid N (list wise) & 239 & & & & \\
\hline
\end{tabular}

4.2.3. Bankers' Perceptions towards Marketing of Islamic Banking Products and Services

Table 6 presents descriptive statistics for five items of the third variable, i.e. bankers' perceptions towards marketing of Islamic banking products and services (BPTMPS). From the mean values of items it is observed that Islamic banks are committed to market, promote and create awareness regarding their products and services in Pakistan.

Table 6: Descriptive Statistics (BPTMPS)

\begin{tabular}{|c|c|c|c|c|c|}
\hline & N & Minimum & Maximum & Mean & Std. Deviation \\
\hline BPTMPS_1 & 239 & 1 & 5 & 4.25 & .729 \\
\hline BPTMPS_2 & 239 & 1 & 5 & 4.22 & .730 \\
\hline BPTMPS_3 & 239 & 1 & 5 & 4.11 & .742 \\
\hline BPTMPS_4 & 239 & 2 & 5 & 4.05 & .763 \\
\hline BPTMPS_5 & 239 & 1 & 5 & 4.19 & .828 \\
\hline Valid N (list wise) & 239 & & & & \\
\hline
\end{tabular}

\subsubsection{Bankers' Perceptions towards Potential Growth of Islamic Banking}

Table 7 presents descriptive statistics for four items of the fourth variable, i.e. bankers' perceptions towards potential growth of Islamic banking (BPTPG). From

Table 7: Descriptive Statistics (BPTPG)

\begin{tabular}{|c|c|c|c|c|c|}
\hline & $\mathrm{N}$ & Minimum & Maximum & Mean & Std. Deviation \\
\hline BPTPG_1 & 239 & 2 & 5 & 4.40 & .584 \\
\hline BPTPG_2 & 239 & 2 & 5 & 4.23 & .638 \\
\hline BPTPG_3 & 239 & 1 & 5 & 4.11 & .759 \\
\hline BPTPG_4 & 239 & 2 & 5 & 4.48 & .673 \\
\hline Valid N (list wise) & 239 & & & & \\
\hline
\end{tabular}


the mean values of items it is observed that employees are confident about potential growth of Islamic banking in Pakistan.

\subsection{Correlations}

Table 8 presents results of correlations among all the variables. As evident from the table, all variables bear a positive relationship with each other, and are significant at $1 \%$ significance level.

Table 8: Correlations Coefficients $(\mathrm{N}=239)$

\begin{tabular}{|c|c|c|c|c|c|}
\hline & & BPTPG & BPTPS & BPTES & BPTMPS \\
\hline \multirow[t]{2}{*}{ BPTPG } & $\begin{array}{l}\text { Pearson Cor- } \\
\text { relation }\end{array}$ & 1 & & & \\
\hline & Sig. (2-tailed) & & & & \\
\hline \multirow[t]{2}{*}{ BPTPS } & $\begin{array}{l}\text { Pearson Cor- } \\
\text { relation }\end{array}$ & $.462^{* *}$ & 1 & & \\
\hline & Sig. (2-tailed) & .000 & & & \\
\hline \multirow[t]{2}{*}{ BPTES } & $\begin{array}{c}\text { Pearson Cor- } \\
\text { relation }\end{array}$ & $.433^{* *}$ & $.412^{* *}$ & 1 & \\
\hline & Sig. (2-tailed) & .000 & .000 & & \\
\hline \multirow[t]{2}{*}{ BPTMPS } & $\begin{array}{l}\text { Pearson Cor- } \\
\text { relation }\end{array}$ & $.488^{* *}$ & $.396^{* *}$ & $.518^{* *}$ & 1 \\
\hline & Sig. (2-tailed) & .000 & .000 & .000 & \\
\hline
\end{tabular}

**. Correlation is significant at the 0.01 level (2-tailed).

\subsection{Regression Results}

Table 9 shows the summary of multiple regression model showing $\mathrm{R}$ square 0.343

Table 9: Regression Results

\begin{tabular}{|c|c|c|c|c|c|}
\hline \multirow{2}{*}{ Model } & \multicolumn{2}{|c|}{ Unstandardized Coefficients } & Standardized Coefficients & \multirow{2}{*}{ T } & Sig. \\
\cline { 2 - 4 } & B & Std. Error & Beta & & \\
\hline (Constant) & 1.155 & .299 & & 3.859 & .000 \\
\hline BPTPS & .332 & .071 & .278 & 4.655 & .000 \\
\hline BPTES & .167 & .064 & .168 & 2.621 & .009 \\
\hline BPTMPS & .248 & .054 & .291 & 4.577 & .000 \\
\hline R Square $=0.343$ and Adjusted R Square $=0.335$ \\
\hline F= 40.903, df $(3,235) \mathrm{p}<0.001$ \\
\hline
\end{tabular}

a. Dependent Variable: Bankers Perceptions towards Potential Growth of IB 
and adjusted $\mathrm{R}$ square 0.335 which means that the model explains almost $34 \%$ of variation in the dependent variable. It means that more than $60 \%$ of the variation in the dependent variable is caused by other factors contributing to the error term. F statistic value is 40.90 , significant at a level of .000 . It is concluded that there is significant relationship between independent variables and dependent variable.

The results support all our hypotheses. Here is the summary for the results and the hypotheses acceptance:

$\mathrm{H}_{1}$ : T-value of BPTPS is 4.65 and adjusted beta was 0.27 with p-value .000 , indicating a significant relationship between BPTPS and BPTPG. Therefore, H1 is accepted.

$\mathrm{H}_{2}$ : T-value of BPTES is 2.61 and adjusted beta is 0.16 , with p-value 0.009 showing significant relationship between BPTES and BPTPG. Therefore, H2 is accepted.

$\mathrm{H}_{3}$ : T-value of BPTMPS is 4.57 and adjusted beta was 0.29 with p-value .000 , reflecting significant relationship between BPTMPS and BPTPG. Therefore, H3 is accepted.

The findings seem to be in line with Zainol et al. (2008) who also observed positive perception of employees about the products and services of Islamic banks, their experience and skills and potential of Islamic banks. They however observed that significant number of employees did not have sufficient knowledge about Islamic banking prior to joining Islamic banks. The current study was different from Zainol et al. (2008) in examining the effects of bankers' perceptions on the potential growth of Islamic banking in Pakistan. The significant relationship between the employees' perceptions and potential growth of Islamic banks presents an optimistic view about the future of Islamic banks in the country.

\section{Conclusion}

Bankers working in Islamic banks appear well-informed and knowledgeable towards products and services offered by Islamic banks, reflecting positive perceptions regarding their compliance with Shari'ah principles and objectives of Islamic banking. They are found quite confident that current practices of Islamic banking are according to the teachings of Islam. Bankers perceive to have gained sufficient experience and skills in Islamic banking. They appear to have extensive knowledge of products and services under their supervision and have received adequate training and exposure before assuming their current post. They also appear confident to solve respective inquiries and problems while dealing with customers and are also encouraged by banks to attend short courses, seminars, and conferences related to their work. 
It is also observed from the bankers' perceptions that the top management of Islamic banks and the government are committed to the development and promotion of Islamic banking products and services in the country. Our survey results also show that bankers are optimistic about the future growth of Islamic banking in Pakistan. They believe that the number of customers including individuals and corporate would increase in the country. However, they are more confident that the numbers of individual customers would increase at a greater rate than the corporate customers. They are also confident about the expansion of Islamic banks in small towns and villages of Pakistan, achieving a target of $20 \%$ market share by the year 2020 as set by the State Bank of Pakistan (SBP, 2013).

Though the bankers working in Islamic banks appear knowledgeable, their performance may further be improved through training and education in Islamic banking. Adequate and proper training regarding products and services of Islamic banking can enhance confidence in employees to deal with customers. Public awareness regarding products and services of Islamic banks in small towns and villages should be created by Islamic banks in order to encourage the expansion of Islamic banking in such places too.

\section{References}

Abdullah, A. A., Sidek, R., \& Adnan, A. A. (2012). Perception of non-Muslims customers towards Islamic banks in Malaysia. International Journal of Business and Social Science, 3(11), 151-163.

Ahmad, N., \& Haron, S. (2008). Perceptions of corporate customers towards Islamic banking products and services in Malaysia. International Journal of Islamic Financial Services, 3(4), 13-19.

Ahmed, G. A. (2008). The implication of using profit and loss sharing modes of finance in the banking system, with a particular reference to equity participation (partnership) method in Sudan. The Journal of Humanomics, 24(3), 182-206.

Ali, S., \& Farrukh, F. (2013). Islamic banking: Is the confidence level of being an Islamic banking employee better than conventional banking employee? An exploratory study regarding Islamic banking. Journal of Business Studies Quarterly, 4(3), 28-42.

Alserhan, B. A., Forstenlechner, I., \& Nakeeb, A. A. (2010). Employees' attitudes towards diversity in a non-western context. The Journal of Employee Relations, 32(1), $42-55$.

Anwar, Y. (2013, August 27). Developments of Islamic banking in Pakistan. Speech presented at the Islamic Finance News Pakistan Road Show, Karachi, Pakistan.

Chapra, M. U. (2007). 21 Challenges facing the Islamic financial industry. Handbook of Islamic Banking, 325-357. 
Dusuki, A. W., \& Abdullah, N. I. (2007). Why do Malaysian customers patronize Islamic banks? International Journal of Bank Marketing, 25(3), 142-160.

Echchabi, A. \& Olaniyi, O. F. (2012). Malaysian consumers' preferences for Islamic banking attributes. International Journal of Social Economics, 39(11), 859-874.

Ernst \& Young. (2012). World Islamic banking competitiveness report 2013: Growing beyond DNA of successful transformation.

Ernst \& Young. (2014). The World Islamic Banking Competitiveness Report, 2013-14, The Transition Begins.

Fauziah, Taib, M., Ramayah, T., \& Abdul Razak, D. (2008). Factors influencing intention to use diminishing partnership home financing. International Journal of Islamic and Middle Eastern Finance and Management, 1(3), 235-248.

Gait, A., \& Worthington, A. C. (2015). Attitudes of Libyan retail consumers toward Islamic methods of finance. International Journal of Islamic and Middle Eastern Finance and Management, 8(4), 439-454.

Hassan, A. \& Latif, H. S. B. A. (2009). Corporate social responsibility of Islamic financial institutions and businesses optimizing charity value. The Journal of Humanomics, 25(3), 177-188.

Khan, M. M. (2008). Main features of the interest-free banking movement in Pakistan (1980-2006). The Journal of Managerial Finance, 34(9), 660-674.

Khan, M. M., \& Bhatti, M. I. (2008). Islamic banking and finance: On its way to globalization. The Journal of Managerial Finance, 34(10), 708-725.

Laldin, M. A. (2008). Islamic financial system: The Malaysian experience and the way forward. The Journal of Humanomics, 24(3), 217-238.

Loo, M. (2010). Attitudes and perceptions towards Islamic banking among Muslims and non-Muslims in Malaysia: implications for marketing to baby boomers and x-generation. International Journal of Arts and Sciences, 3(13), 453-485.

Mahomedy, A. C. (2013). Islamic economics: Still in search of an identity. International Journal of Social Economics, 40(6), 556-578.

Malik, M. S., Malik, A., \& Mustafa, W. (2011). Controversies that make Islamic banking controversial: An analysis of issues and challenges. American Journal of Social and Management Sciences, 2(1), 41-46.

Marimuthu, M., Wai Jing, C., Phei Gie, L., Pey Mun, L., \& Yew Ping, T. (2010). Islamic banking: Selection criteria and implications. Global Journal of Human-Social Science Research, 10(4), 52-62.

Mellahi, K., \& Budhwar, P. S. (2010). Introduction: Islam and human resource management. Personnel Review, 39(6), 685-691. 
Mokhtar, H. S. A., Abdullah N., \& Alhabshi, S. M. (2008). Efficiency and competition of Islamic banking in Malaysia. The Journal of Humanomics, 24(1), 28-48.

Muhamad, R., Melewar, T. C. \& Alwi, S. F. S. (2012). Segmentation and brand positioning for Islamic financial services. European Journal of Marketing, 46(7/8), 900-921.

Ramzan, M., Zahid, A., Hussain, N., Islam, K., Aziz, F. \& Ghazenfer, S. K. (2012). Growth of Islamic banking in Pakistan by Using AID model. International Journal of Business and Social Science, 3(23), 152-164.

Rostamy, A. A. A. (2009). Toward understanding conflicts between customers and employees' perceptions and expectations: Evidence of Iranian bank. Journal of Business Economics and Management, 10(3), 241-254.

Rustam, S., Bibi, S., Zaman, K., Rustam, A., \& Haq, Z. U. (2011). Perceptions of corporate customers towards Islamic banking products and services in Pakistan. The Romanian Economic Journal, 41, 107-123.

Santos, J. R. A. (1999). Cronbach's alpha: A tool for assessing the reliability of scales. Journal of extension, $37(2), 1-5$.

Shah, B. A., \& Niazi, G. S. K. (2009). Contemporary practices of Islamic banks in Pakistan: A critical appraisal. Int. J. Monetary Economics and Finance, 2(3/4), 302-316.

Shakespear, R., \& Harahap, S. (2009). The comparative role of banking in binary and Islamic economy. The Journal of Humanomics, 25(2), 142-162.

Siddiqi, M. N. (2001). Recent history of Islamic banking and finance. Islamic Economic Studies, 13(2), 1-48.

State Bank of Pakistan. (2013). Islamic Banking Bulletin: 2013. Retrieved from http://www.sbp.org.pk/ ibd/bulletin/2013/IBB-Sep-2013.pdf.

State Bank of Pakistan. (1980). BCD Circular No. 26 dated 24.12.1980.

Trabelsi, M. A. (2011). The impact of the financial crisis on the global economy: Can the Islamic financial system help. The Journal of Risk Finance, 12(1), 15-25.

Usmani, T. M. (2011). An introduction to Islamic finance. Maktabah Ma'ariful Quran, Karachi.

Vahed, G., \& Vawda, S. (2008). The viability of Islamic banking and finance in a capitalist economy: A South African case study. Journal of Muslim Minority Affairs, 28(3), 453-472.

Wilson, R. (2002). The evolution of the Islamic financial system. In Archer S., \& Abdel Karim, R. A. (Eds.), Islamic Finance: Innovation and Growth. (pp. 29-41). Euromoney books: London.

Zamil, N. A. M. (2014). An empirical investigation into the problems and challenges facing Islamic banking in Malaysia (Doctoral dissertation, Cardiff Business School).

Zainol, Z., Shaari, R., \& Ali, H. M. (2008). A comparative analysis of bankers' perceptions on Islamic banking. International Journal of Business and Management, 3(4), 157-168. 
Appendix-A

\section{List of Islamic Banking Institutions \\ As of December 31, 2015}

\section{A. Islamic Banks}

1. AlBaraka Bank (Pakistan) Ltd.

2. BankIslami Pakistan Ltd.

3. Burj Bank Ltd.

4. Dubai Islamic Bank Pakistan Ltd

5. MCB Islamic Bank Ltd.

6. Meezan Bank Ltd

B. Conventional Banks having Islamic Banking Branches

1. Askari Bank Ltd.

2. Allied Bank Ltd.

3. Bank Al Habib Ltd

4. Bank Alfalah Ltd

5. Faysal Bank Ltd.

6. Habib Bank Ltd

7. Habib Metropolitan Bank

8. MCB Bank Ltd

9. National Bank of Pakistan

10. Silk Bank Ltd 10 Silk Bank Ltd

11. Sindh Bank Ltd

12. Soneri Bank Ltd

13. Standard Chartered Bank 
14. Summit Bank Ltd.

15. The Bank of Khyber

16. The Bank of Punjab

17. United Bank Ltd.

Grand Total $23(6+17)$

(Source: SBP, Quarterly Compendium: Statistics of the Banking System, December 2015)

\section{Appendix-B}

\section{Questionnaire}

Dear Respondent!

Thank you for agreeing to fulfill this questioner. This survey is being conducted to study Determining Bankers' Perception towards Islamic Banking Practices and Growth in Pakistan, for purely academic purpose. I would like to ensure that the information / feedback provided by you will be kept confidential and will only be used for the purpose of research. Your cooperation in this regard shall be highly appreciated.

Please read each question carefully and tick a box to indicate the answer 
Section 1:- (Please tick the appropriate check box below)

\begin{tabular}{|c|c|c|c|c|}
\hline Gender & Age & Education & Designation & Bank \\
\hline$\square$ Male & $\square 20-25$ & $\begin{array}{c}\square \text { Diploma and } \\
\text { below }\end{array}$ & $\square$ Branch Manager & $\begin{array}{c}\square \text { Full-fledged Islamic } \\
\text { Bank }\end{array}$ \\
\hline$\square$ Female & $\square 26-30$ & $\square$ Bachelor's Degree & $\square$ Operation Officers & $\begin{array}{c}\square \text { Conventional Bank } \\
\text { with Islamic Branch }\end{array}$ \\
\hline & $\square 31-35$ & $\square$ Master Degree & $\square$ Lending Officers & \\
\hline & $\square 36-40$ & $\square$ MS/M.Phil & $\square$ Senior Officers & \\
\hline & $\square 41-45$ & $\square$ PhD & $\square$ Relationship Manager & \\
\hline & $\square 46-50$ & Other_--------- & Other_-------- & \\
\hline & $\square$ Above 50 & & & \\
\hline
\end{tabular}

Section 2:- (Please tick the appropriate checkbox below)

\begin{tabular}{|c|c|c|c|c|c|}
\hline $\begin{array}{c}\text { Perceptions of bankers in Islamic banks } \\
\text { towards Islamic banking products and } \\
\text { services. }\end{array}$ & $\begin{array}{c}\text { Strongly } \\
\text { Agree }\end{array}$ & Agree & Neutral & Disagree & $\begin{array}{c}\text { Strongly } \\
\text { Disagree }\end{array}$ \\
\hline $\begin{array}{c}\text { Islamic banking is according to Shari'ah } \\
\text { which differentiates it from conventional } \\
\text { banking. }\end{array}$ & $\square$ & $\square$ & $\square$ & $\square$ & $\square$ \\
\hline $\begin{array}{c}\text { The Islamic banking system must adhere } \\
\text { profit loss sharing principle. }\end{array}$ & $\square$ & $\square$ & $\square$ & $\square$ & $\square$ \\
\hline $\begin{array}{c}\text { Muslims are attracted towards Islamic } \\
\text { banking because Riba is prohibited in } \\
\text { Islam. }\end{array}$ & $\square$ & $\square$ & $\square$ & $\square$ & $\square$ \\
\hline $\begin{array}{c}\text { Islamic banking is introduced to promote } \\
\text { social and welfare economic system. }\end{array}$ & $\square$ & $\square$ & $\square$ & $\square$ & $\square$ \\
\hline $\begin{array}{c}\text { Islamic banking is a viable alternative to } \\
\text { conventional banking. }\end{array}$ & $\square$ & $\square$ & $\square$ & $\square$ & $\square$ \\
\hline $\begin{array}{c}\text { Islamic banking addresses the reserva- } \\
\text { tions of Muslims towards conventional } \\
\text { banking. }\end{array}$ & $\square$ & $\square$ & $\square$ & $\square$ & $\square$ \\
\hline $\begin{array}{c}\text { Islamic banking is capable to accomplish } \\
\text { with demand of customers to bring inno- } \\
\text { vative products and services. }\end{array}$ & $\square$ & $\square$ & $\square$ & $\square$ & $\square$ \\
\hline $\begin{array}{c}\text { Islamic banking customers are concerned } \\
\text { about service quality and price. }\end{array}$ & $\square$ & $\square$ & $\square$ & $\square$ & $\square$ \\
\hline
\end{tabular}




\begin{tabular}{|c|c|c|c|c|c|}
\hline $\begin{array}{l}\text { Perceptions of bankers in Islamic banks } \\
\text { towards experience and skills gained in } \\
\text { Islamic banks. }\end{array}$ & $\begin{array}{l}\text { Strongly } \\
\text { Agree }\end{array}$ & Agree & Neutral & Disagree & $\begin{array}{l}\text { Strongly } \\
\text { Disagree }\end{array}$ \\
\hline $\begin{array}{l}\text { Proper training and exposure is given on } \\
\text { the products and services before they are } \\
\text { launched. }\end{array}$ & $\square$ & $\square$ & $\square$ & $\square$ & $\square$ \\
\hline $\begin{array}{l}\text { Extensive knowledge on the products } \\
\text { and services under my supervision. }\end{array}$ & $\square$ & $\square$ & $\square$ & $\square$ & $\square$ \\
\hline $\begin{array}{c}\begin{array}{c}\text { Employees capable to solve customers' } \\
\text { problems. }\end{array} \\
\end{array}$ & $\square$ & $\square$ & $\square$ & $\square$ & $\square$ \\
\hline $\begin{array}{c}\text { Adequate training and exposure before } \\
\text { assuming the current post. }\end{array}$ & $\square$ & $\square$ & $\square$ & $\square$ & $\square$ \\
\hline $\begin{array}{l}\text { Bankers are encouraged to attend } \\
\text { short-courses, seminars and conferences } \\
\text { in related field. }\end{array}$ & $\square$ & $\square$ & $\square$ & $\square$ & $\square$ \\
\hline $\begin{array}{c}\text { Perceptions of bankers in Islamic banks } \\
\text { towards marketing of Islamic banking } \\
\text { products and services. }\end{array}$ & $\begin{array}{l}\text { Strongly } \\
\text { Agree }\end{array}$ & Agree & Neutral & Disagree & $\begin{array}{l}\text { Strongly } \\
\text { Disagree }\end{array}$ \\
\hline $\begin{array}{l}\text { Your bank management shows com- } \\
\text { mitment in marketing and promoting } \\
\text { Islamic banking products and services. }\end{array}$ & $\square$ & $\square$ & $\square$ & $\square$ & $\square$ \\
\hline $\begin{array}{l}\text { Your bank management shows com- } \\
\text { mitment in creating public awareness } \\
\text { regarding Islamic banking products and } \\
\text { services. }\end{array}$ & $\square$ & $\square$ & $\square$ & $\square$ & $\square$ \\
\hline $\begin{array}{l}\text { Marketing tools utilize by your bank to } \\
\text { promote their products and services. }\end{array}$ & $\square$ & $\square$ & $\square$ & $\square$ & $\square$ \\
\hline $\begin{array}{c}\text { Islamic banks market their Islamic bank- } \\
\text { ing products and services in an effective } \\
\text { manner. }\end{array}$ & $\square$ & $\square$ & $\square$ & $\square$ & $\square$ \\
\hline $\begin{array}{l}\text { The Pakistan government shows com- } \\
\text { mitment to further developing Islamic } \\
\text { banking in Pakistan. }\end{array}$ & $\square$ & $\square$ & $\square$ & $\square$ & $\square$ \\
\hline $\begin{array}{c}\text { Perceptions of bankers' in Islamic banks } \\
\text { towards potential growth of Islamic } \\
\text { banking in Pakistan. }\end{array}$ & $\begin{array}{l}\text { Strongly } \\
\text { Agree }\end{array}$ & Agree & Neutral & Disagree & $\begin{array}{l}\text { Strongly } \\
\text { Disagree }\end{array}$ \\
\hline $\begin{array}{l}\text { Usage of Islamic banking products and } \\
\text { services by individuals will increase. }\end{array}$ & $\square$ & $\square$ & $\square$ & $\square$ & $\square$ \\
\hline $\begin{array}{l}\text { Usage of Islamic banking products and } \\
\text { services by corporate sector will increase. }\end{array}$ & $\square$ & $\square$ & $\square$ & $\square$ & $\square$ \\
\hline
\end{tabular}




\begin{tabular}{|c|c|c|c|c|c|}
\hline $\begin{array}{c}\text { Islamic banking will expand in small } \\
\text { town and big villages in Pakistan beside } \\
\text { first tier cities. }\end{array}$ & $\square$ & $\square$ & $\square$ & $\square$ & $\square$ \\
\hline $\begin{array}{c}\text { You are convinced that Islamic banking } \\
\text { will achieve a set target of 20\% market } \\
\text { share by the year 2020. }\end{array}$ & $\square$ & $\square$ & $\square$ & $\square$ & $\square$ \\
\hline
\end{tabular}

